\title{
Expanding the Domain of Festival Research: A Review and Research Agenda
}

\begin{abstract}
Festivals are an important sub-field within event studies which, until recently, have not been studied as separate experiences. A systematic review of the emerging literature on festivals reveals several key characteristics. While festivals are diverse in nature and geographical location, scholarly interest focuses on five main themes across these variations: the motivations for organising, funding, and attending festivals; the experiences of festival attendees; the relationship between festivals and their local environments; the economic and socio-cultural impacts of festivals; and the management of festivals. Despite growing interest in festivals as research sites, little attention has been afforded to investigating festival processes. In particular, considerations of how festivals are established, and which individuals are involved in their initiation and regular staging, offer opportunities for research. This article highlights the significant role festivals play within their local communities, including their facilitation of social cohesion and regional identity. Our study reveals that the literature rarely discusses the development of festivals over time and the wider networks in which festivals are embedded. This critical review of festival research identifies various research gaps and directions for future research to develop theory and practical understanding of festivals.
\end{abstract}

\section{Keywords}

Embeddedness; festival research; festival tourism; local communities; process

\section{Acknowledgements}

The authors would like to express their sincere appreciation to Aviel Dodge-Cogan for her research assistance. We are also grateful to the three anonymous reviewers and Editor Oswald Jones for their valuable feedback and constructive comments. Financial support from the British Academy/Leverhulme Small Research Grants is gratefully acknowledged. 


\section{Introduction}

Festivals can have a significant impact on local communities by providing value added activities and spending outlets for locals and visitors, and by enhancing the image of a destination (Getz et al. 2006; Grunwell and Ha 2007; Quinn 2006). The development of festivals is thus increasingly regarded as a strategy for local economic development (Getz et al. 2010) and greater place attachment. As a result, festivals are becoming an important target of economic policies and, at regional and local levels, regeneration initiatives (Boo and Busser 2005; Waterman 1998). To date, festival research has concentrated on economic impacts (Litvin et al. 2013; Rao 2001); analysis and profiling of attendees and audiences (Prentice and Anderson 2003; Song et al. 2014); and investigations of operational and managerial aspects (Frisby and Getz 1989; Frost and Laing 2015). Less research has investigated those involved in staging festivals or the factors and processes contributing to their outcomes (Gursoy et al. 2004). This article seeks to broaden our understanding of festivals and to highlight research avenues, with a particular emphasis on the actors and processes that support festivals.

There is a well-established domain of literature attesting to the significant benefits generated by festivals across economic, political, and sociocultural domains (Andersson and Getz 2009; Quinn 2005). Furthermore, prior research on festivals has demonstrated the positive impact festivals can have by increasing tourism, providing spending opportunities, attracting additional funding for local communities and regions, and creating employment (Crompton and McKay 1997; Kim et al. 1998; Thrane 2002). Such research has also observed the wider social effects that local, community-based festivals can have, for example, on perceptions of place and locale (Getz and Frisby 1988), on generating revenues, and in supporting existing ventures and encouraging business start-up (Gursoy et al. 2004). 
In this article, we present a Systematic Literature Review (SLR) of festival research. By providing an overview of the diverse and disjointed literature on festivals, we advance knowledge of this important sub-field of event studies and encourage further dedicated research. This review reveals that five key themes are of particular interest to festival scholars: motivation, experience, place, impact, and management. This article also highlights under-explored areas. Accordingly, we develop a research agenda and propose that future studies investigate (1) where the ideas for festivals originate, (2) which individuals are involved, (3) how these actors interact and collaborate, (4) which resources festivals require, and (5) how the networks of relationships needed to organise festivals evolve over time.

This article is structured as follows. First, we define festivals and outline their fundamental characteristics before detailing our methodological approach. Dominant themes in existing research are then discussed before research gaps are identified and recommendations are made to inform future scholarship in this field.

\section{Defining festivals}

A large number of conceptualisations of festivals are used in the literature. While the scope of festivals is varied, including agriculture, arts, cultural, and local community themes, common characteristics can be identified. Festivals are events held at a particular point in time; they are repeated and open to the public. Uysal and Gitleson (1994) define festivals as 'traditional events staged to increase the tourism appeal to potential visitors' (p. 3), while Saleh and Ryan (1993) state that, 'by their nature, festivals are of short duration, and generally based around a theme' (p. 290). More recently, Getz et al. (2010) proposed that 'festivals celebrate community values, ideologies, identity and continuity' (p. 30). Festivals enhance their communities' economies and landscapes, but their success often depends on whether volunteers can be encouraged to dedicate their time to these events (Getz and Frisby 1988; 
Gursoy et al. 2004). Festivals also often 'create a sense of belonging and pride among local residents, thus fostering the sharing of local resources and local purchases' (Julien 2007. p. 246). Furthermore, festivals are highly dependent on the driving forces of key individuals acting within festival networks, who support their emergence and occurrence on a regular basis (Gursoy et al. 2004).

The challenge in defining festivals lies in differentiating festivals from events and special events. Festival research originated as part of event studies and has only recently emerged as a distinct field of study. Consequently, prior research has not always made a clear distinction between festivals and events. It has been argued that the key differences between festivals and other events are festivals' central focus on celebration of cultural and social dimensions, and the involvement of multiple stakeholders (Getz et al. 2010). Festivals differ from special events as they occur on a regular basis, whereas 'a special event is a onetime or infrequently occurring event outside the normal range/programme or activities of the sponsoring or organising body' (Getz 1997, p. 44).

Building on these prior conceptualisations, we broadly define festivals as public, themed celebrations that are held regularly. This definition and the distinctions between festivals, events and special events informed the methodology undertaken to perform a systematic review of the festival literature. The implications on the data collection are discussed in the next section.

\section{Methods}

To examine the depth and breadth of published research on festivals, we conducted an SLR as advocated by Tranfield et al. (2003) and Macpherson and Jones (2010). As discussed by Wang and Chugh (2014), adopting this systematic process increased the rigour, validity, and generalisability of the review compared to traditional, ad hoc literature review approaches. 
Appendix S1 (in the Supporting Information) provides a summary of the SLR process we employed in this study.

\section{Conceptual boundaries}

The first step in the SLR process involved setting research objectives and defining conceptual boundaries (Denyer and Tranfield 2008). The primary goal of our review was to analyse and critique festival research with a view to developing a research agenda for further study. Accordingly, we sought to evaluate themes and trends in the extant literature. To facilitate the advancement of festival research, we chose to investigate a broad range of subject areas and journals. However, this presented us with a challenge, as research on festivals covers a multitude of topics and adopts a variety of perspectives. To account for this breadth of research, we adopted an inclusive approach and defined festivals broadly as public, themed celebrations that are held regularly. Another challenge we encountered was distinguishing between literature on festivals, events and special events. Prior research has frequently used these terms interchangeably which limited our ability to develop search terms that allowed an automated selection of articles for inclusion in our review (de Mol et al. 2015) and necessitated a large amount of manual selection work, as described below.

\section{Data collection and analysis}

To develop a comprehensive database of festival studies, we employed several inclusion and exclusion criteria. Following other SLRs (Adams et al. 2015; Mabey 2013), we limited our search to articles published in academic journals listed in the Association of Business Schools (ABS) Academic Journal Guide 2015 (Wood and Peel 2015). Although the ABS guide has been subject to some criticism (Willmott 2011), it is 'widely seen as capturing the consensus in relation to journal ratings' (Rowlinson et al. 2011, p. 443). We focused our review on 6 
subject categories, which we anticipated would feature the majority of dedicated festival studies: 'Entrepreneurship and Small Business Management', 'General Management, Ethics and Social Responsibility', 'Marketing', 'Regional Studies, Planning and Environment', 'Sector Studies', and 'Social Sciences'. Within these categories, we targeted high quality journals ranked at Grade 4 and 3. As Baldacchino et al. (2015) argue, publication in such journals "provides a "stamp of quality" (p. 215), which facilitates identifying articles of appropriate standard and rigorous design. To increase our coverage and to ensure all relevant papers were included in this study, we also reviewed articles in journals ranked at Grade 2 and 1 if they were published in a special issue on festivals (e.g. Larson 2009; Robertson and Rogers 2009) or in a dedicated journal. We identified two such journals, namely Event Management (formerly titled: Festival Management and Event Tourism) and International Journal of Event and Festival Management.

As shown in Appendix S2 (in the Supporting Information), we initially conducted full-text searches for the term 'Festival*' in the 113 journals that met the above inclusion criteria. We searched the journals' electronic databases for the period up to and including June 2015. This process produced almost 5000 articles in 105 journals, which implies that festivals are of relevance to a broad range of subjects and studies. However, less than $10 \%$ of these papers mention 'Festival*' in the abstract or title, which indicates that dedicated festival research is comparatively rare. These 438 dedicated articles were then 'skim read (rapid scanning of the entire article)' (Iqbal et al. 2015, p. 511) to allow refining of the sample. We adopted this manual selection process, rather than narrowing the search through additional search terms, to ensure that all relevant articles were included in the review. We excluded articles if they investigated events and listed festivals only as an example of an event or if they were set within festival contexts but did not investigate topics particular to festivals (for a full list of exclusion criteria, see Appendix S1 in the Supporting Information). 
The papers were independently screened by two of the authors, who discussed any discrepancies on inclusion/exclusion. This selection process resulted in a total of 160 journal articles. To reduce the risk that the rigidity of the systematic review process led to the exclusion of key articles, we conducted an independent search of Google Scholar to confirm the results of our search (de Mol et al. 2015; Wang and Chugh 2014). This process also enabled us to determine the most frequently cited papers in our review (see Appendix S3 in the Supporting Information).

Two authors independently coded the articles selected for review. Firstly, papers were coded according to pre-defined themes (Nolan and Garavan 2015; Wang and Chugh 2014) including: (1) Name(s) of author(s), (2) Year of publication, (3) Journal title, (4) Subject area, (5) Type(s) of festival(s), (6) Context, (7) Methods, (8) Sample, and (9) Core argument. Secondly, in order to categorise articles, we developed codes that described their main areas of interest. We followed an 'open coding' approach, which allowed the identification of key themes (Strauss and Corbin 1990). Any differences in the resulting coding were discussed and articles were revisited until agreement was reached, which ensured a high degree of interrater reliability (Wang and Chugh 2014). During this iterative process, we discovered 5 main themes: motivation, experience, place, impact, and management, which divided into 21 subthemes that describe the various topics which festival studies have investigated (on average 2 themes per article in this review). As shown in Appendix S4 (in the Supporting Information), some themes, such as festivals' economic and socio-cultural impacts, have received considerably more attention than others. The primary objective of adopting this review approach was to explore main themes and patterns within festival research and to determine gaps that warrant further investigation. 


\section{Themes and trends in the literature}

This literature analysis is based on 160 articles (see Appendix S5 in the Supporting Information for a full list of reviewed articles). The results of our analysis are presented below, structured according to the thematic codes previously described and focusing on main themes and trends in the literature.

Figure 1. Festival Studies Publication Distribution

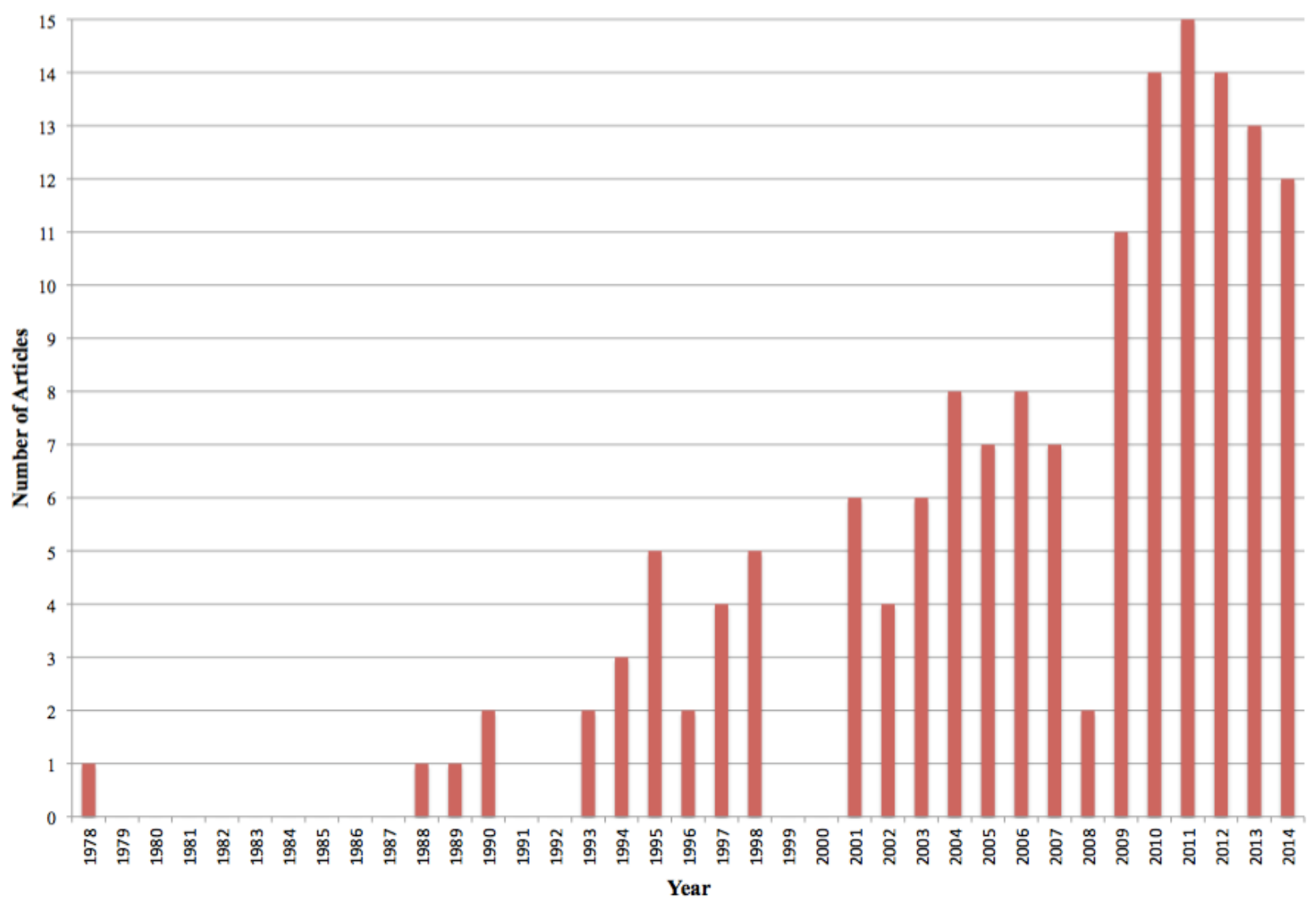

Note: Although our literature review incorporated articles up to and including June 2015, this figure displays articles up to 2014 only to avoid misrepresentation of articles published in 2015. It should be noted that 7 articles were published between January and June 2015.

\section{Publication distribution}

This section reports findings regarding the publication distribution of the reviewed articles. As illustrated in Figure 1, scholars have investigated festivals for over 35 years. The earliest relevant article was published in 1978 and discussed the attitudes of communities towards 
festivals (Heenan 1978). While it explored an interesting topic that continues to receive academic attention (Frost and Laing 2015; Quinn 2005), Heenan's (1978) article did not generate an immediate response within the academic community. It took 10 years before the call for further research on festivals was heeded (Frisby and Getz 1989; Getz and Frisby 1988). Subsequently, several of the most frequently cited papers were published in the late 1990s and early 2000s (see Appendix S3 in the Supporting Information). Following these seminal works, there has been a sharp increase of scholarly interest in festival research. Almost half the articles in this review $(n=75)$ have been published since 2010. Getz is notable in the development of festival discourse, as he has authored numerous influential papers (e.g. Getz 2002; Getz et al. 2006) and served as a founding editor of Festival Management and Event Tourism (now titled: Event Management), the first dedicated festival journal, inaugurated in 1993.

As shown in Appendix S6 and S7 (in the Supporting Information), festival studies have been published in a number of highly recognised journals, including Annals of Tourism Research $(\mathrm{n}=7)$, Journal of Travel Research $(\mathrm{n}=26)$ and Tourism Management $(\mathrm{n}=18)$. The majority of papers $(n=147)$ belong to the subject area of Tourism Research which is incorporated under 'Sector Studies' in the ABS Guide (Wood and Peel 2015). Within this subject area, Event Management has featured the highest number of relevant articles $(\mathrm{n}=59)$. However, festival studies have also been published in 'Regional Studies, Planning and Environment' $(\mathrm{n}=10)$, 'Social Sciences' $(\mathrm{n}=2)$ and 'Entrepreneurship and Small Business Management' $(\mathrm{n}=1)$. Surprisingly, no relevant papers have been disseminated via highly ranked journals in 'General Management, Ethics and Social Responsibility' or 'Marketing'. As noted in Appendix S4 (in the Supporting Information), there are several studies that explore issues relating to general management (Ferdinand and Williams 2013; Larson 2009) and marketing (Hudson et al. 2015; Kruger and Saayman 2013), but these have all been 
published in 'Sector Studies'. As festival research develops into a distinct field of study, it is likely that dedicated research will gain acceptance in other recognised academic journals across disciplines.

\section{Research methods and contexts}

This systematic review identified a number of methodological trends. Our sample includes 149 empirical studies, 5 primarily conceptual papers (3 of which provide some empirical validation for their arguments) and 6 literature reviews. Whilst the majority of empirical research was quantitative (101 articles), an increasing number of studies employed qualitative (32) and mixed method approaches (16). Almost all quantitative studies used surveys as their data collection method (a notable exception was Jiang et al. 2015), although some drew on secondary data (Litvin and Fetter 2006; Litvin et al. 2006). It was found that a majority of these studies were cross-sectional - only a limited number adopted longitudinal approaches. Also, while there has been development of various measurement scales (Small 2007; Tkaczynski and Stokes 2010), these have rarely been used in subsequent research and, as such, their reliability and generalisability are yet to be tested. Exceptions include Woosnam et al. (2013) who confirmed Delamere's (2001) Festival Social Impact Attitude Scale, and Getz et al. (2010) whose cross-cultural analysis of festivals was based on earlier work (Getz et al. 2006). Furthermore, although these scales do diverge to some degree, 'a great deal of redundancy exists in items and resulting dimensions across the scales' (Woosnam et al. 2013, p. 258).

The qualitative studies in this review predominantly adopted single case designs (examples of multiple case studies include: Jaeger and Mykletun 2013; O'Sullivan and Jackson 2002) and were based on interview and observational data. The single case approach has enabled detailed examination of festivals at one point in time. Consequently, temporal 
considerations have yet to receive significant research attention. Even though almost all studies in this review were set within the positivist paradigm (Burrell and Morgan 1979), some recent examples have embraced alternative paradigms, including critical realism (Jepson et al. 2013; Vestrum 2014) and interpretivism (Frost and Laing 2015; Stadler et al. 2013). To develop the field of festival research, we advocate further paradigmatic diversity.

Empirical festival studies have explored a variety of contexts. However, the majority have investigated festivals within national contexts (notable exceptions include: Andersson and Getz 2009; Carlsen and Andersson 2011), particularly within North America, Europe (primarily the UK, Norway and Sweden) and Australia. Notwithstanding, some studies have examined festivals in Asia (Chang 2006; Dewar et al. 2001), especially South Korea (Jeong and Santos 2004; Shin 2004), Central and South America (Báez and Devesa 2014; Nurse 2004) and Africa (Kruger and Saayman 2013; Van Zyl and Botha 2004). Further research in a broader range of regions could greatly enhance our understanding of differences between festivals. Within these national contexts, many studies have focused on specific types of festivals. Frequently investigated were music (Edwards 2012; Karlsen and Stenbacka Nordström 2009), food and drink (Axelsen and Swan 2010; Yuan and Jang 2008), history (Childress and Crompton 1997; Kim and Jamal 2007) and art festivals (Seaton 1997; Waterman 1998). Furthermore, a vast body of research has examined cultural (Johansson and Kociatkiewicz 2011; Matheson et al. 2014) and community festivals (Chacko and Schaffer 1993; Lee and Kyle 2014). Consequently, understanding is limited regarding alternative themes, such as gender (Van Den Berg 2012), wildlife (Hvenegaard 2011; Lawton and Weaver 2010), and nature (Song et al. 2012). The field of festival research could greatly benefit from further studies of such under-explored festival themes. 


\section{Understanding festivals: The evidence}

As detailed in Appendix S4 (in the Supporting Information), our systematic review of festival research identified five key themes, each of which is critically examined in this section.

\section{Motivation}

Motivational research into festival attendance became popular in the 1990s (Formica and Uysal 1998; Saleh and Ryan 1993). Various theoretical frameworks have been used to position studies on motivations within festival research, including Maslow's (1943) needhierarchy; Iso-Ahola's (1980) escape-seeking dichotomy; and push (escape) and pull (seeking) factors. Numerous studies have delineated these motivational factors, suggesting that a core set of drivers for festival attendance exists, including 'cultural enrichment, education, novelty and socialization' (Crompton and McKay 1997, p. 429). Recent studies on motivations have predominantly focused on the relationship between these factors and festival quality (Kim et al. 2010; Lee et al. 2004). Understanding what motivates people to attend festivals is important; such knowledge can inform not only the design of festivals, ensuring that they meet attendees' expectations, but also the planning of festivals, guiding their operational efficiency (Lee and Kyle 2014).

Most studies on motivations are positioned at an aggregate level, with a focus on how to classify and segment festivals attendees and identify factors that motivate their visits (Lee and Kyle 2014; Kim et al. 2006; Uysal et al. 1993). Market segmentation is a powerful tool as it provides knowledge of visitor identities and allows an understanding of the relationship between the characteristics of festivals and their visitors (Thompson and Schofield 2009). Furthermore, segmenting visitors and identifying their specific needs and behaviours enables festival organisers to develop effective marketing strategies and, ultimately, ensure their longterm economic viability (Crompton and McKay 1997). This is critical as, despite their 
popularity, festivals typically fail more often than they thrive (Lee and Kyle 2014; Getz 2002). Extant studies tend to focus on a priori or a posteriori segmentation (Kim et al. 2006). A priori segmentation concentrates on pre-known variables such as gender, age, income and nationality, whilst a posteriori segmentation employs variables determined as a result of observation to differentiate between clusters of visitors (Kim et al. 2006; Formica and Uysal 1998).

A comparatively small number of studies have examined the motivations of different groups of attendees, exploring the relationship between motivations, related activities, and levels of participant satisfaction (Lee et al. 2004; Formica and Uysal 1998). Uysal et al. (1993) undertook one of the first studies into the dimensions of motivation, which led to numerous subsequent investigations of underlying motivations for festival attendance (Báez and Devesa 2014; Kim et al. 2006). Interestingly, socialisation was found to be a dominant pull factor, rather than simply an experiential by-product of festival attendance (Chang 2006; Formica and Uysal 1998; Thompson and Scholfied 2009). Other common motivators are the novelty of the festival and the ability to visit with family (Van Zyl and Botha 2004; Thrane 2002; Crompton and McKay 1997).

Research to date focuses on four main areas of market segmentation with respect to festival attendance: demographics, geography, psychographics, and behaviours (Song et al. 2012; Tkaczynski 2013; Yolal et al. 2012). It has been argued that segmentation studies need to consider other approaches to classifying attendees as an alternative to segmentation by motivation (Tkaczynski and Rundle-Thiele 2011). Current methods of stratification are considered inferior because of their limited capacity to provide insights into visitors' psychological needs (Lee and Kyle 2014). Recent research suggests the usefulness of psychological variables, which are rarely applied in market segmentation (Tkaczynski 2013). For example, despite the fact that 'commitment-based segmentation criteria enable marketers 
to recognise more homogeneous subgroups of visitors and predict behaviour such as repeat visitation and word-of-mouth promotion' (Lee and Kyle 2014, p. 656), these measures are under-utilised for understanding festival attendees.

Another dominant theme discovered in the motivation literature relates to the organisation and funding of festivals. This literature ranges from government intentions in initiating a festival to motivations of residents who provide festivals with financial support (Van Aalst van Melik 2012; Edwards 2012). Festivals often require significant public investment. Sponsors and governments are usually willing to provide economic aid because their financing ensures festivals' sustainability and economic benefits (Tomljenovic and Weber 2004). Information regarding motivations of those attending festivals can also be used to tempt sponsors and various stakeholders to assist with festival costs (Grunwell and Ha 2005; Shin 2004). This is becoming an increasingly important aspect of festival management (Bowen and Daniels 2005). Furthermore, it is argued that festivals provide a means of connecting local communities and can therefore be regarded as a public good (Rao 2001). Sponsors and stakeholders are aware that, by supporting festivals within communities, they help stimulate local economies and foster a positive image of the destination (Johansson and Kociatkiewicz 2011; Van Aalst and van Melik 2012). However, scholars also recognise that the traditional financial routes for festival funding are not well developed and often face many constraints (Lin et al. 2011).

\section{Experience}

A number of studies have found a connection between attendees' festival experiences and their satisfaction and loyalty (Lee et al. 2012; Yoon et al. 2010). In particular, research has uncovered the significance of festival quality (Kim et al. 2010; Lee and Beeler 2009; Lee et al. 2007). Many of these investigations use data on satisfaction levels as a means of 
evaluating previous experiences and perceptions of the festival's physical environment. Satisfaction with this experience is both emotional and evaluative (Mason and Paggiaro 2012; Song et al. 2014) and has been defined as 'a judgement that a product, or service feature, or the product or service itself, provides a pleasurable level of consumption-related fulfilment' (Oliver 1997, p. 13). In the tourism literature, the dominant paradigm has been the expectancy-disconfirmation approach, which links pre-purchase expectations, perceived performance, disconfirmation and satisfaction (Childress and Crompton 1997). Other approaches focus only on perceived actual performance. This second type of approach is considered particularly apposite in a festival setting, where prior expectations may be difficult to measure as the consumer may have little knowledge of the festival experience (Yoon et al. 2010).

The environment of the festival has been referred to as the festivalscape, a term coined by Lee et al. (2008), who draw upon retail servicescape literature. A festivalscape is an amalgam of the tangible factors and the intangible 'atmosphere' associated with a festival which informs how people relate to the festival. These include dimensions of ambient factors, aesthetic, functional, and social factors. Combined within the festivalscape, these features are regarded as antecedents to satisfaction. Key findings within the literature on festivalscapes include the conclusions that festival programme quality and the accessibility of ancillary facilities are critical to attendee satisfaction (Lee et al. 2004; Song et al. 2014; Yolal et al. 2012).

There has been empirical support for a relationship among experience, perceived value, and satisfaction and for a link between these impressions and behavioural intentions (Lee et al. 2012; Mason and Paggiaro 2012). Satisfaction with festivals was shown to act as a strong antecedent to loyalty, positively revising attitudes and future behaviours (Grappi and Montanari 2011; Song et al. 2014; Yoon et al. 2010). Furthermore, it has been found that 
attachments to a certain cultural community have a significant impact not only on intentions to revisit festivals year after year, but also on spreading positive word of mouth (Lee et al. 2012). Perceived destination image has proved to be a strong factor in encouraging repeat visits to specific festivals (Felsenstein and Fleischer 2003). Additionally, festivals have been found to provide a context for social relationships and shared experiences, which help foster satisfaction and loyalty. In a study of factors influencing attendees' retention, Grappi and Montanari (2011) discovered that hedonism and social identification are key facilitators of satisfaction and repeat visitation. Satisfaction with a festival has also been found to lead to loyalty to the host destination (Lee et al. 2012), with satisfied visitors displaying place attachment.

Other work in this area focuses on the authenticity of attendees' experience itself, rather than object-based authenticity. This notion of existential authenticity builds on Wang's (2000) argument that festivals liberate individuals to behave in ways that give them an authentic sense of self, allow them to explore multiple alternative identities, and provide them with an 'intensified and concentrated experience of an alternative Being-in-the-World' (p. 65). In their key paper, Kim and Jamal (2007) focus on highly committed participants at the themed Texas Renaissance Festival. They find that, in these liminal zones, people can reconstruct their desired selves and desired relationships. The festival setting provides a 'safe place' where these explorations can occur and both intrapersonal factors, relating to the body and self-making, and interpersonal factors, relating to the touristic communities, were found to be important in the experience of the festival.

\section{Place}

Four themes were identified within the festival literature relating to the topic of place: (1) destination image, (2) regional identity, (3) festival tourism, and (4) cultural politics. 
An enduring theme within the festival literature is the effect of festivals on the images of destinations. For example, Boo and Busser (2006) found that, after attending a festival on the Korean island of Jeju, both attendees and non-festival tourists held more negative images of the destination. The main reasons cited for this were the insufficient and misleading festival promotion and disappointing experiences of the festival while visiting the island. This suggests that, when using festivals to enhance the image of a destination, it is important to widely communicate its programme and to ensure that visitors' expectations are met by their experiences while attending the festival. Based on this, it is recommended that, despite the extensive resource implications, the staging of local festivals in tourist destinations needs to be more effectively marketed (McKercher et al. 2006).

Van Den Berg's (2012) case study of the 'La City' festival in Rotterdam provides an interesting perspective on the use of festivals to change the image of a place. Specifically, it demonstrates use of a 'genderfication' strategy to encourage urban renewal and to change the image of a destination from one of masculinity and post-industrialisation to one of a servicebased, 'feminine', new economy. Van Den Berg's (2012) findings indicate that while efforts to encourage a more feminine image may have been effective with certain audiences, such as white, middle-class women, they simultaneously excluded others, including ethnically diverse populations.

Early research also identified a strong relationship between festivals and regional identity, arguing that promoting a festival is closely linked to promoting the place and its cultural values (Waterman 1998). Later research has questioned the strength of this relationship. For example, Prentice and Andersen (2003) explored the contribution of the Edinburgh Festival on tourists' images of the country and found that, across all segments, the festival was regarded as distinct from mainstream Scottish culture. This raises the question of how important the location of a festival is when seeking to provide tourists with an authentic 
festival experience. Similarly, Van Aalst and Melik's (2012) case study of the relocation of a festival from The Hague to Rotterdam challenges the impact of host regions and their identities on attendees' perceptions of performance quality. By contrast, research that examined the emotional and social ties people have to particular locations stressed the benefits of linking places with festivals (Arellano 2011). Accordingly, Lee et al. (2012) recommend that festival organisers promote positive visitor experiences at festivals if they wish to encourage place attachment and loyalty.

Another recurring theme within the literature is festival tourism (Oh and Lee 2012). While early work on this phenomenon drew attention to the benefits of festival tourism for local economies, it also highlighted the need for more effective exploitation of the opportunities for sustainable economic development afforded by festivals (O'Sullivan and Jackson 2002). Developing this, Quinn (2005) revealed that organisers regard urban festivals as having multiple outcomes on tourist numbers, community celebrations, and engagements. Her analysis concludes that, while city authorities concentrate on the economic impact of festivals, they often regard them as "quick fix" solutions to city image problems' (p. 939) and fail to recognise the social worth created by urban festivals. Building on this and using the concept of the experience economy, Johansson and Kociatkiewicz (2011) examined three urban festivals to better understand their effectiveness in attracting globally mobile visitors. Their finding that urban festivals generate a mix of both positive (friendly tourist image) and negative outcomes (crime) questions both the link between place and festival and the positive benefits of festivals, suggesting a research gap concerning the darker side of festivals and their negative consequences.

A final theme concerns the effects of locales' cultural politics on festivals (Waterman 1998; Williems-Braun 1994). For example, Shin's (2004) study of festivals staged by a local government in South Korea provides insights into the tensions between culture, politics, 
place, and the varying demands of competing interest groups, which can result in these festivals having the opposite effect from that planned. In Shin's (2004) example, rather than changing the image of the city, the Gwangju Biennale festival became 'intimately linked to the city's political history and image' (Shin 2004, p. 619) and not divorced from it. Jeong and Santos's (2004) study also highlights the implications of cultural politics when using festivals to change the image of a place. Their study found that deep-rooted cultural norms and political beliefs hamper the potential for festivals to generate outcomes supportive of creating better equality, rights, and justice. However, considering the small number of studies that have perused this avenue of research, further research is needed to explore the impact of local cultural politics on festivals.

\section{Impact}

A significant characteristic of festivals is that they 'require minimal capital development and take advantage of existing infrastructure ... [yet] have the potential for generating substantial returns on small financial investments' (Gursoy et al. 2004, p. 171). Festivals can be seen as a way of generating local income and creating jobs in the short term, increasing visits from those outwith the area, and as a means of seeking longer-term investment (Jackson et al. 2005). Furthermore, festivals can revitalise and expand existing markets and bring economic benefits (Chhabra et al. 2003; Litvin et al. 2013).

While these rewards can be significant, researchers studying festival impacts argue that there is an incentive for festival organisers to exaggerate the benefits of holding a festival to the local community and potential sponsors as a means of attaining support (Crompton and McKay 1994; Jackson et al. 2005). Over-estimation of economic benefits can happen in a number of ways. Firstly, it can entail the inclusion of tourists who would have visited an area anyway, but happen to arrive during the festival. Secondly, it can be achieved through the 
incorporation of people who choose to attend the festival, but visited the area for a different reason. Thirdly, it can occur through the inclusion of expenditures from local residents that represent a diversion from alternative local expenditures. Finally, it can be a result of a failure to account for incremental municipal and other related costs and the loss of revenue from displaced visitors and the opportunity costs of public funds devoted to the festival (Litvin and Fetter 2006; Litvin et al. 2006). Further critiques include claims that the focus is often on short-term over long-term impacts and that multiplier effects do not consider costs or distribution of gains or the extent to which the area might be better off without the festival (Felsenstein and Fleischer 2003; Litvin et al. 2013).

While financial outcomes have been the focus of the majority of impact studies, festivals have a range of objectives and, therefore, the means of evaluating their impacts needs to be adapted accordingly. For instance, they can be used strategically to re-position or rebrand a city or region in a form of 'civic boosterism' (Shin 2004) or to target special interest markets to meet social and environmental goals (Hvenegaard 2011; Rollins and Delamere 2007; Van Winkle and Woosnam 2014).

There is a growing recognition that the social impacts of festivals on their host communities need to be measured. In many cases, economic factors may not be of paramount concern. Rather, the purpose may be to build social cohesion by reinforcing community ties a goal that could be attained by actively involving community members in planning and running festivals (Gursoy et al. 2004; Rao 2001; Van Winkle and Woosnam 2014). In a study of indigenous festivals in Australia, Whitford and Ruhanen (2013) found strong support for the socio-cultural benefits of festivals on their host communities, such as capacity building through the development of social capital, cultural preservation, and reconciliation. Social impacts were found to be dependent upon levels of engagement by the community (Jepson et al. 2013; Vestrum 2014) with a direct link between knowledge and engagement and with 
community empowerment fostering a more positive attitude towards the festival.

In many instances, promoting a local festival results in conflicting effects. A festival may generate economic benefits, enhance local quality of life, and create community solidarity whilst simultaneously causing environmental damage, increasing traffic congestion, and adding to law enforcement costs (Gursoy et al. 2004). Researchers have used a number of scales to assess the social impacts of festivals, including the Social Impact Perception Scale (SIPS) (Gursoy et al. 2004; Small 2007; Whitford and Ruhanen 2013) and the Festival Social Impact Attitude Scale (FSIAS) (Delamere et al. 2001; Rollins and Delamere 2007). These scales diverge to some extent, but also have a number of overlapping constructs. Consequently, there are calls from researchers for further refinement and application of the scales to a number of festival contexts to improve robustness and reliability of the measures used and to enable further examination of potential theoretical relationships between constructs (Woosnam et al. 2013).

\section{Management}

A final theme identified within the literature was that of festival management. Research in this area has broadened its scope from a focus on feasibility, administration, design, marketing, operations, and risk (Larson 2002) to an acknowledgement of the wider environmental context in which festivals operate (Andersson et al. 2013; Edwards 2012). It has been argued that an analysis of festival management needs to adopt an integrative approach accounting for factors that drive the initiation of festivals at the outset, their planning and management, their outcomes, and the interplay between them (Getz et al. 2010). Such an integrative framework would allow the scope of festival research to extend beyond management functions to consider the involvement of and interactions between the wider community networks involved in planning and managing festivals (Andersson et al. 2013; 
Quinn 2006). This would significantly improve festival management studies because business operations are, in one way or another, conducted in social structures, implying that social interactions and relationships can affect business success in terms of competitiveness and potential profit (de Klerk and Saymaan 2012).

Festival management is a complex area, which involves programming, financial planning, marketing, and service provision (Carlsen et al. 2010). It has been noted that, when managing a festival, attention should also be given to the needs of 'local residents, community groups, businesses, public bodies, sponsors, shareholders, and tourists' (Rogers and Anastasiadou 2011, p. 387). How a festival is managed is highly important, as this influences funding decisions. For example, funders may require the festival to meet specific aims, which include (1) cultural goals: preserving and promoting tradition and heritage which will provide national and international exposure for the place and people; (2) economic aims: contributing to the overall economic development; and (3) community objectives: revitalising the town, increasing tourism, and attracting culturally motivated visitors (Tomljenovic and Weber 2004).

In addition, founders' motivations, such as community engagement and creation of social wealth, have a considerable impact on management practices (Ferdinand and Williams 2013; Vestrum 2014). As the changes that festival organisers seek to effect usually take time to embed into local structures, management planning needs to evolve alongside community and social developments. Importantly, relationships have been found to play a decisive role in facilitating changes that are based on trust and reciprocity; particularly, relationships help ensure that key actors become and remain involved, guaranteeing that festivals continue to be valued in the long-term (Frisby and Getz 1989). As Getz (1991) finds, in most cases, festival attendees are predominantly local residents, reinforcing the argument that building 
relationships with communities over time is key to the success of festivals and must be embraced as a core management activity.

Another essential aspect of organising and managing festivals is devising a budget suitable for the character and size of the festival. For example, larger festivals require more human resources and marketing than smaller festivals, which are often comprised of volunteers and local community assistance. Larger festivals also require more planning and control, and present greater operational challenges (Smith et al. 2010). While there are general guidelines for festival organisation, managing a festival is not a linear process. The causes of festival failure, which extend well beyond simple financial failure, are often related to internal forces, such as insufficient marketing, poor planning, lack of human or financial resources, and ineffectual organisational cultures. For instance, Getz (2002) reports that festivals in Calgary have a high rate of failure because of high financial debt, disorganisation, inability to meet funders' remits, and price restrictions.

Culture is also often regarded as a fundamental element within the management of festivals, because organisational structures vary across festivals. One systematic difference lies within organisations' ownership and purposes (Getz 1997). Festivals can be organised by private companies whose aim is to make a profit or by governments and local communities who anticipate social or cultural impacts (Einarsen and Mykletun 2009). Festival organisers can significantly affect the culture and resulting success or failure of their festivals (Getz 2002). For example, while coherent and stable organisational cultures can benefit festival management, organisations that struggle with governance issues, including succession planning and problems with leadership, are disadvantaged by their organisational cultures (Stadler et al. 2013). Such complications are particularly common for small festival organisations (Frost and Laing 2015). In response to such festival-specific organisational issues, it has been argued that festival management research must provide more dedicated 
advice that is not based on the findings of generic events research or general management theory to better support the development of festivals over time (Stadler et al. 2013; Getz et al. 2010).

\section{Discussion}

After over 35 years of scholarship, dedicated festival research has seen a sharp increase since 2010. Although the majority of papers are classified under 'Sector Studies', festival studies have also been published in other subject areas, including 'Entrepreneurship and Small Business Management', 'Regional Studies, Planning and Environment' and 'Social Sciences'. We anticipate that alternative perspectives on festival research will continue to develop as the context lends itself to the application of broader business management theories (Getz et al. 2010). The evidence reviewed in this study indicates that festival research has focused on five key areas: motivations, experience, place, impact, and management, and reveals research gaps respective to each of these themes.

Studies of motivations have focused on examining core sets of drivers and developing segmentation strategies particular to festival attendees. It is argued that an understanding of attendees' motivations can inform and influence festival design and guide operational

efficiency (Lee and Kyle 2014). Segmentation strategies can also be employed to aid understanding of the motivational drivers of different groups of attendees. However, as most existing studies limited their investigations to demographic, geographical and behavioural factors (Song et al. 2012; Tkaczynski 2013; Yolal et al. 2012), there are enduring gaps in understanding of the breadth of motivations that drive people to attend festivals, particularly their psychological motivations (Lee and Kyle 2014). Additionally, studies need to broaden their focus to further understand the motivations of sponsors, stakeholders, volunteers, and others involved in managing, organising, and financing festivals. 
Research on experiences of festivals has concentrated on visitors and attendees and has highlighted the relationships between individual festival experiences, satisfaction, and loyalty to festivals (Lee et al. 2012; Mason and Paggiaro 2012). The notion of a festivalscape has been suggested as a way of framing visitors' experiences, as it incorporates both intangible factors, such as the festival atmosphere and the shared experiences of attendees, and tangible factors, including the festival programme and available facilities (Lee et al. 2004; Song et al. 2014; Yolal et al. 2012). Prior studies have also explored the authenticity of the festival experience and its connection to individual participants' self-identity (Wang 2000; Kim and Jamal 2007). However, we argue that extant research has not sufficiently considered the experiences of those residing in locales where festivals are staged and of festival organisers, managers, and volunteers. Investigating the perspectives of such parties would allow future studies to consider broader experiences of festivals.

Findings regarding the places where festivals occur have concentrated on destination image, regional identity, and associated implications for festival marketing and promotion. It is argued that festival organisers should make use of effective marketing communication to cultivate a destination image which matches visitors' expectations and experiences (Boo and Busser 2006). If a festival can achieve a clear connection with its place, this can be used as a critical tool to support the promotion of regional identity and cultural values (Waterman 1998). Studies in this area have called for examinations of the various impacts that festivals exert on places, taking into account broader social impacts (Quinn 2008). A limited strand of research has also investigated the strategic use of place through a cultural-political lens, where festivals are used to change perceptions of a city (Waterman 1998; Willems-Braun 1994). While this research recognises that festivals can generate multiple and mixed outcomes for the places in which they are staged, it overlooks the darker side of festivals, including negative outcomes on locales, such as their social, political and environmental 
legacies.

Studies measuring the impact of festivals have concentrated on their economic benefits and have only recently begun to consider the wider benefits of festivals, including their socio-cultural and community outcomes (Organ et al. 2015; Vestrum 2014). Not only do economic impacts dominate festival research, but these are also often exaggerated to justify the existence of the festival and garner support, mostly in the form of financial contributions (Crompton and McKay 1994; Jackson et al. 2005). Additionally, negative impacts of festivals have been understated by a focus on short-term, rather than long-term, impacts (Litvin et al. 2013). Thus, calls have been made for the measurement of broader cultural and social impacts (Van Winkle and Woosnam 2014) and for the refinement of exisiting measurement scales through further empirical testing (Woosnam et al. 2013). It would therefore be beneficial for future research to investigate the multiple impacts of festivals on local communities and the interplay between community engagement and festival outcomes.

A similar gap has been identified in research on festival management: a need to better understand the variety of actors involved in initiating, managing, and organising festivals, as well as closer consideration of the interplay between the wider communities involved in staging festivals. The scope of prior studies has been broadened from a focus on feasibility, administration, design, marketing, operations, and risk (Larson 2002) to an acknowledgement of the wider environmental context in which festivals operate (Edwards 2012). There are calls for a more integrative approach to understanding festival management which takes into account social interactions and relationships (Andersson et al. 2013; Getz et al. 2010). Furthermore, greater appreciation of stakeholder engagement is required to understand the critical nature of relationship building with local communities and its impact on the mobilisation and acquisition of resources (Tomljenovic and Weber 2004). By extending research to incorporate the multiple agendas and anticipated outcomes of different 
stakeholders, and the effects of these on initiating and maintaining festivals, it is likely that implications for practice, policy and theory will emerge.

From a methodological standpoint, it is important to note that our review found the majority of festival studies to be empirical in nature (only 5 reviewed articles were primarily conceptual and 6 were literature reviews). While this is typical of early stage research in any field of social science, it is critical that future studies engage in greater theoretical development. We recommend that borrowing concepts and theories from more established social sciences might be fruitful in supporting such theory building. We also note that much of the existing empirical research is quantitative and specific to a single point in time. To both build theory and advance knowledge we recommend that festival studies embrace greater methodological diversity, including qualitative studies, mixed methods and, importantly, longitudinal research. These approaches will allow for processes to be examined and the effects of varying motivations, expectations and management practices to be better understood.

\section{Research Agenda}

The preceding discussion of research themes highlights a need to widen the focus of festival research. Accordingly, we propose a research agenda to inform future festival studies. This agenda represents the most important contribution of our review to the field of festival research. As shown in Figure 2, we recommend that future studies consider four key aspects of festivals, the interplay between these elements, and their implications for the outcomes and success of festivals. These aspects include 1) the pre-festival stage, including the founder(s) and festival initiation; 2) the partnerships between festival stakeholders, which are required to establish and stage festivals on a regular basis; 3) the variety of resources provided by these 
partnerships; and 4) the processes involved in staging festivals, from their initiation through to their repetition.

We believe that this agenda has the potential to offer new insights into the driving forces, local conditions, and community dynamics relevant to the initiation and staging of festivals. This is supported by a recognition that, whilst the economic and social prospects of festivals are attracting growing policy, academic, and media interest, comparatively little is known about the micro-level processes upon which festivals are established. This problem has been exacerbated by a lack of understanding concerning the broader range of actors involved in and affected by festivals. While attendees and festival managers have been considered, the involvement of residents, communities, volunteers, and other stakeholders in initiating festivals, and the effects of festivals on these actors have received scant research attention. Furthermore, the interactions between these different actors and the processes in which they engage to establish and stage festivals on a regular basis are under-researched.

Figure 2. Research Agenda for Festival Research

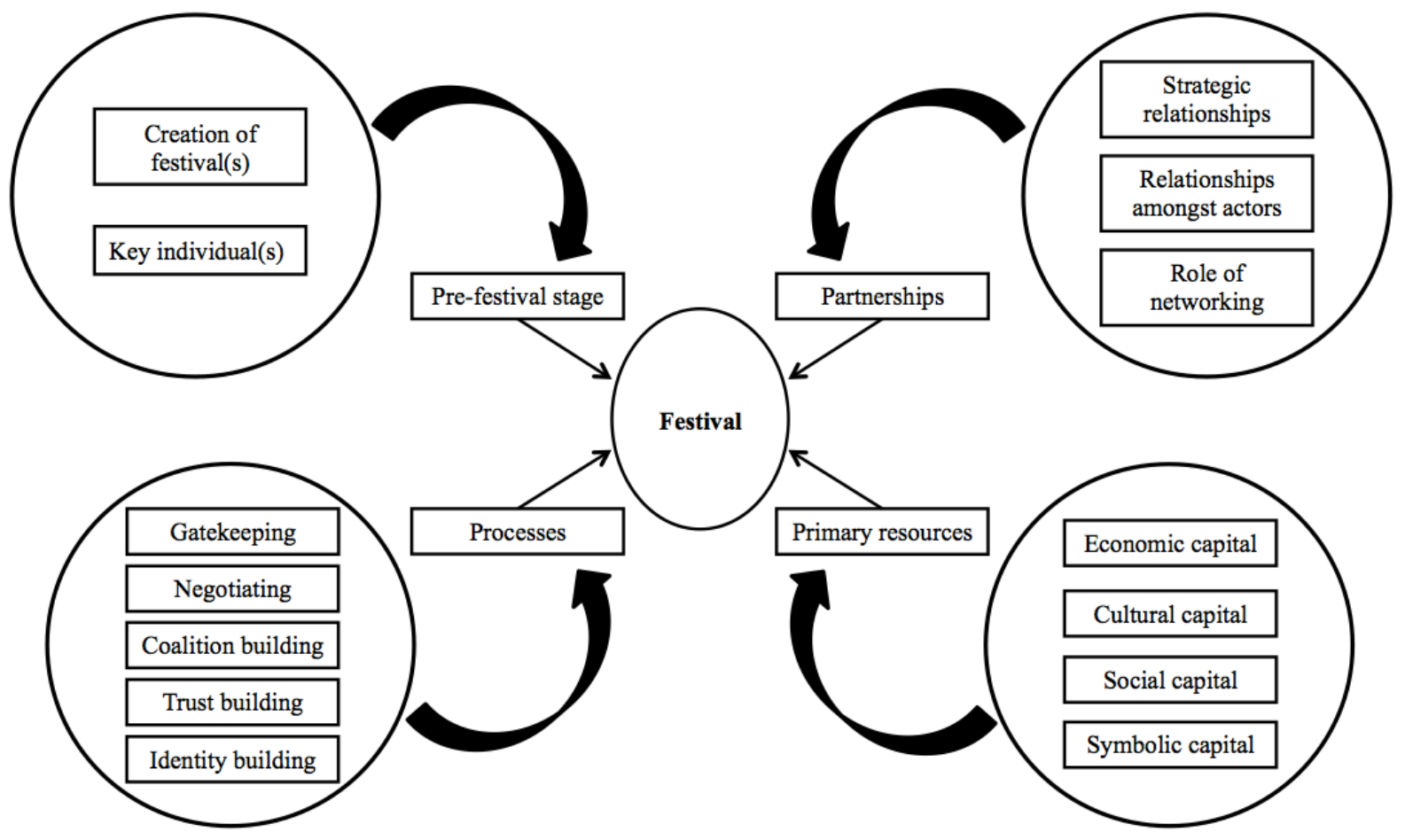


Pre-festival stage and the role of the festival founder

The festival literature is dominated by studies that explore the execution of festivals. Consequently, the literature neglects the 'pre-festival' stage. In this SLR, we found only two papers that discuss the role of the festival founder in the initiation of festivals (Edwards 2012; Vestrum 2014). Notably, both are from outwith the field of festival and event studies (Journal of Rural Studies and Entrepreneurship and Regional Development, respectively).

Edwards (2012) presents a historical analysis of a national country music festival in Australia, which focuses on the first 25 years of the event. His findings point to the influence of existing 'countryside capital' (p. 517) and emergent community capacity on the development of this festival and highlight the critical role of the founding family in its success. In a longitudinal study of the initiation and development of a jazz festival in a rural Norwegian community, Vestrum (2014) focuses on the key festival founder and how his participation in community activities allowed for the mobilisation of resources. These studies provide a promising starting point, and we argue that similar work is needed to aid understanding of the early stage of festival initiation. Specifically, two areas are ripe for investigation: how festivals are created and the key individuals involved.

Given the inhibitors of time, costs, resource needs, administration duties and uncertain outcomes, we need to explore more fully what drives founders to create their festivals. The relationship between the creation of a festival and the festival founder as an individual has yet to receive adequate attention. Furthermore, given that the sustainability of festivals has become increasingly important to local communities, governments and policy-makers (Chhabra et al. 2003), founders' continuing commitment to their festivals poses an interesting and relevant avenue for future enquiries (Einarsen and Mykletun 2009; Ferdinand and Williams 2013). The development of theory that can explain and predict the conditions under 
which festivals thrive would be particularly helpful in enhancing knowledge of the key individuals who are involved in their perpetuation. The resulting knowledge about festivals founders, including their motivations, expectations, experiences, and anticipated outcomes, could help inform understanding of the impact and legacy of festivals.

\section{Partnerships}

The role of partnerships is an important, yet largely unexplored, domain of festival research. Given the portfolio of funding and bootstrapping of festival resources, we argue that investigating the partnerships which provide access to these resources is both appropriate and necessary to fully appreciate and understand the multiple actors and organisations involved in staging festivals. We found only one study which empirically examined the role of networking in the festival sector. De Klerk and Saayman's (2012) profiling of festival founders and their relationships with others highlighted the importance of 'soft' factors, including trust, and stressed the effects of commitment, reciprocity, proximity and strength of relationships on the ability of networking to have a positive impact on festival success.

To supplement this individual study, we identify three areas for further research within the domain of partnerships: strategic relationships, relationships amongst actors, and the role of networking. The notion of strategic relationships can be applied to festival research to enhance our understanding of the benefits that manifest from these types of associations. Strategic relationships often involve an agreement between two or more entities (for example, the festival and key stakeholders) to conduct specified activities or processes (including creating and sustaining a festival) to achieve specified objectives (such as positive economic and social impacts) (Boyle 1997). These formal relationships have increasingly been appreciated as critical for festival success and sustainability (Jepson et al. 2013). Furthermore, we argue that informal relationship building also plays an important role for 
festivals. These relationships include the key individuals' recruitment of volunteers to commit to, assist, and support the creation and continuance of the festival. Volunteers bring with them their skills, access to individual networks, time, and a sense of duty towards the community (Larson 2009). In attracting participants to become part of the festival, informal relationships also enhance the festival offerings to the general public (Vestrum 2014). Strategic and less formal relationship building is aided by the role of networking, which is initially conducted by the festival founder alone. Once relationships are formed, networking becomes a self-perpetuating process, which provides access to resources both within and outwith the communities in which the festivals are embedded (Einarsen and Mykletun 2009).

More established research from outside of festival studies, particularly within the entrepreneurship literature, has also demonstrated the benefits of partnerships and social networks for the establishment of new ventures (Jack 2010; Slotte-Kock and Coviello 2010). Given the parallels between firm creation and festival initiation, we argue that festival researchers should borrow from their peers in the field of entrepreneurship. In drawing upon the relevant entrepreneurship literature, scholars can better understand the partnerships and networks on which festival founders may draw to acquire the resources needed to regularly stage festivals. Such insights will advance understanding of festival management by both illuminating those with whom festival founders interact and partner to access needed resources and by encouraging the exploration of the interactions involved in developing such partnerships and benefiting from networks.

\section{Primary Resources}

Surprisingly, research on the resources required to stage festivals is largely absent from the festival research literature. While it is acknowledged that the financial viability of festivals is often precarious and that local governments are frequently involved in supporting festivals 
(Shin 2004), there has been little serious consideration of the amount and types of resources needed to be able to run a festival. We argue that applying broader social science concepts, such as embeddedness (Granovetter, 1985) and capital theory (Bourdieu, 1986), to the study of festivals will provide much needed insights into the types and amounts of resources that those involved in staging festivals can acquire from the networks in which they are embedded.

Drawing on Bourdieu's (1986) capital theory, we suggest that future research differentiate between economic, cultural, social, and symbolic forms of capital and investigate their influence on the processes of establishing and staging festivals. As discussed by Pret et al. (2015), economic capital refers to financial and other business assets; cultural capital relates to long-lasting personal dispositions, educational qualifications (often associated with human capital) and cultural goods; social capital is 'the sum of all actual and potential resources that can be accessed through a durable network of relationships' (p. 4); and symbolic capital refers to the prestige, status, and reputation that can be accumulated to legitimise business practices.

Scholars interested in the resources required to initiate and stage festivals are likely to find capital theory a useful theoretical lens through which the experiences of key actors can be interpreted. Specifically, by employing this conceptual framework, future research could investigate the ways in which individual forms of capital might be leveraged to access other forms and to compensate for any lack of capital, such as financial resources. Thus, adopting this approach could help develop theories that explain festival survival and success.

Importantly, we propose that future studies incorporate not only economic and social capital, but also cultural and symbolic capital into their investigations of festival processes. While prior research has demonstrated that financial resources and social networks are important for developing and staging festivals (Carlsen et al. 2010), there is a lack of 
understanding regarding the influence of cultural resources, such as associations with talented artists (Bell and Jayne 2010), and symbolic assets, such as reputation and standing within the host community, on the success and continuation of festivals.

\section{Processes}

Despite the reality that festivals are often repeated on a regular - typically annual - basis, research on festivals has largely ignored the processes involved in initiating and repeatedly staging festivals. Instead, most research has focused on festivals at a single point in time. We argue that an understanding of the success and impact of festivals must be informed by an appreciation of pre-festival processes and a consideration of post-festival reflections. We thus anticipate benefits from revisiting the same festival over several years to explore differences in motivations, experiences, and impacts over time. While prior research has considered the public-facing aspects of festivals, including their impacts and outcomes, we propose that future research should also seek to explore the more hidden processes involved. Such research could provide insights into the actions of key actors involved in developing and staging festivals (e.g. festival founder(s) and key stakeholders) and help illustrate the processbased nature of festivals. Activities such as gatekeeping, negotiating, coalition building, trust building, and identity building should receive particular attention from future research (Larson 2002).

More research is required on the critical role of the gatekeeper in the delivery of a successful festival. This curating role is under-explored. It involves developing the festival programme and attracting the right balance of participants to fit with the expectations of the intended audience. The process of gatekeeping constitutes the founder exerting power over which acts and participants will be included in the festival process. How such decisions are made is largely unknown (Vestrum 2014). Gatekeeping also requires negotiation between 
participants and organisers. This negotiation is dependent upon the reputations of and relative power balance between those involved, such as the founder(s) and stakeholders, and upon the draw of the festival itself.

Coalition building allows the key founder(s) to legitimise the festival, draw upon current relationships and networks to enable a wider impact, gain access to resources, and strengthen influential ties (Clarke and Jepson 2011). Trust within the festival process depends on the reputation, past performance, and experience of the festival. In the case of a new festival, trust can be gained through networks, individual reputations, and coalition building. Trust gives access to resources, influences decision-making, and allows for legitimacy building, thus ensuring the festival's future success (Getz et al. 2006). External validation of the festival can be achieved through identity building. Such validation (or non-validation) comes from outlets such as the media, government, competitors, and attendees. Given the importance of these elements, their future investigation offers the potential for empiricallyinformed theory building about festival processes which will inform a richer understanding of festival management practices.

\section{Conclusion}

This literature review and analysis reveals that, while prior studies have explored diverse festivals, scholarly interest has focused on only five key areas: motivations, experience, place, impacts, and management. Despite growing interest in festivals as a focus of research, little attention has been given to investigating actors or processes, in particular, how festivals become established, who is involved in their initiation and how they develop over time.

This article highlights the significant role festivals play within local communities and reveals that the continuance of festivals and the wider networks in which they are embedded are rarely discussed. In our proposed research agenda, we highlight the importance of 
understanding festivals as a continuum and the people, processes, and resources that are key to their initiation and successful development. The focus of festival research has broadened in scope from the initial literature concerning impacts, profiling of attendees, and festival management. We identify new avenues of research at a micro level, which concern the prefestival stage, partnerships, primary resources and processes. Future research in this vein should improve understanding of where the idea for festivals originate, which individuals are involved, how these actors interact and collaborate, which resources festivals require, and how the networks of relationships needed to organise festivals evolve over time.

Acknowledging that work in this area is still at an early stage, we call for further conceptual studies to aid the development of theory and suggest that concepts and theories from more established social sciences may be fruitful in supporting such theory building. We argue that empirical foci should move beyond case studies of festivals at a single point in time towards longitudinal studies that can aid understanding of festival processes and the shifting roles of the multiple actors involved in their initiation and development. 


\section{References}

Adams, R., Jeanrenaud, S., Bessant, J., Denyer, D. and Overy, P. (2015). Sustainabilityoriented Innovation: A Systematic Review. International Journal of Management Reviews. DOI: 10.1111/ijmr.12068 (early online publication)

Andersson, T.D. and Getz, D. (2009). Tourism as a mixed industry: Differences between private, public and not-for-profit festivals. Tourism Management, 30, pp. 847-856.

Andersson, T.D., Getz, D. and Mykletun, R.J. (2013). Sustainable festival populations: An application of organizational ecology. Tourism Analysis, 18, pp. 621-634.

Arellano, A. (2011). A History of Quebec_-Branded: The Staging of the New France Festival. Event Management, 15, pp. 1-12.

Axelsen, M. and Swan, T. (2010). Designing Festival Experiences to Influence Visitor Perceptions: The Case of a Wine and Food Festival. Journal of Travel Research, 49, pp. $436-450$.

Báez, A. and Devesa, M. (2014). Segmenting and profiling attendees of a film festival. International Journal of Event and Festival Management, 5, pp. 96-115.

Baldacchino, L., Ucbasaran, D., Cabantous, L. and Lockett, A. (2015). Entrepreneurship Research on Intuition: A Critical Analysis and Research Agenda. International Journal of Management Reviews, 17, pp. 212-231.

Bell, D. and Jayne, M. (2010). The creative countryside: Policy and practice in the UK rural cultural economy. Journal of Rural Studies, 26, pp. 209-218.

Boo, S. and Busser, A.J. (2005). Impact Analysis of a Tourism Festival on Tourists Destination Images. Event Management, 9, pp. 223-237.

Bourdieu, P. (1986). The Forms of Capital. In Richardson, J.G. (ed.), The handbook of theory and research for the sociology of education. New York, NY: Greenwood Press, pp. $241-258$. 
Bowen, H.E. and Daniels, M.J. (2005). Does the music matter? Motivations for attending a music festival. Event Management, 9, pp. 155-164.

Boyle, M. (1997). Civic boosterism in the politics of local economic development? 'Institutional positions' and 'strategic orientations' in the consumption of hallmark events. Environment and Planning A, 29, pp. 1975-1997.

Burrell, G. and Morgan, G. (1979). Sociological Paradigms and Organizational Analysis. London: Heinemann Educational Books.

Carlsen, J. and Andersson, T.D. (2011). Strategic SWOT analysis of public, private and notfor-profit festival organisations. International Journal of Event and Festival Management, 2, pp. 83-97.

Carlsen, J., Andersson, T.D., Ali-Knight, J., Jaeger, K. and Taylor, R. (2010). Festival management innovation and failure. International Journal of Event and Festival Management, 1, pp. 120-131.

Chacko, H.E. and Schaffer, J.D. (1993). The evolution of a festival: Creole Christmas in New Orleans. Tourism Management, 14, pp. 475-482.

Chang, J. (2006). Segmenting tourists to aboriginal cultural festivals: An example in the Rukai tribal area, Taiwan. Tourism Management, 27, pp. 1224-1234.

Chhabra, D., Sills, E. and Cubbage, F.W. (2003). The Significance of Festivals to Rural Economies: Estimating the Economic Impacts of Scottish Highland Games in North Carolina. Journal of Travel Research, 41, pp. 421-427.

Childress, R.D. and Crompton, J.L. (1997). A Comparison of Alternative Direct and Discrepancy Approaches to Measuring Quality of Performance at a Festival. Journal of Travel Research, 36, pp. 43-57.

Clarke, A. and Jepson, A. (2011). Power and hegemony within a community festival. International Journal of Event and Festival Management, 2, pp. 7-19. 
Crompton J.L. and McKay S.L. (1994). Measuring the Economic Impact of Festivals and Events: Some Myths, Misapplications and Ethical Dilemmas. Festival Management and Event Tourism, 2, pp. 33-43.

Crompton, J.L. and McKay, S.L. (1997). Motives of visitors attending festival events. Annals of Tourism Research, 24, pp. 425-439.

de Klerk, S. and Saayman, M. (2012). Networking as key factor in Artpreneurial success. European Business Review, 24, pp. 382-399.

de Mol, E., Khapova, S.N. and Elfring, T. (2015). Entrepreneurial Team Cognition: A Review. International Journal of Management Reviews, 17, pp. 232-255.

Delamere, T.A. (2001). Development of a Scale to Measure Resident Attitudes Toward the Social Impacts of Community Festivals, Part II. Verification of the Scale. Event Management, 7, pp. 25-38.

Delamere, T.A., Wankel, L.M. and Hinch, T.D. (2001). Development of a Scale to Measure Resident Attitudes Toward the Social Impacts of Community Festivals, Part I: Item Generation and Purification of the Measure. Event Management, 7, pp. 11-24.

Denyer, D. and Tranfield, D. (2008). Producing a systematic review. In Buchanan, D. (ed.), The Sage Handbook of Organizational Research Methods. London: Sage, pp. 671689.

Dewar, K., Meyer, D. and Li, W.M. (2001). Harbin, lanterns of ice, sculptures of snow. Tourism Management, 22, pp. 523-532.

Edwards, R. (2012). Gympie's country music Muster: Creating a cultural economy from a local tradition. Journal of Rural Studies, 28, pp. 517-527.

Einarsen, K. and Mykletun, R.J. (2009). Exploring the Success of the Gladmatfestival (The Stavanger Food Festival). Scandinavian Journal of Hospitality and Tourism, 9, pp. $225-248$. 
Felsenstein, D. and Fleischer, A. (2003). Local Festivals and Tourism Promotion: The Role of Public Assistance and Visitor Expenditure. Journal of Travel Research, 41, pp. 385392.

Ferdinand, N. and Williams, N.L. (2013). International festivals as experience production systems. Tourism Management, 34, pp. 202-210.

Formica, S. and Uysal, M. (1998). Market Segmentation of an International CulturalHistorical Event in Italy. Journal of Travel Research, 36, pp. 16-24.

Frisby, W. and Getz, D. (1989). Festival Management: A Case Study Perspective. Journal of Travel Research, 28, pp. 7-11.

Frost, W. and Laing, J. (2015). Avoiding burnout: the succession planning, governance and resourcing of rural tourism festivals. Journal of Sustainable Tourism, pp. 1-20.

Getz, D. (1991). Festivals, Special Events, and Tourism. New York, NY: Van Nostrand Reinhold.

Getz, D. (1997). Event management and event tourism. New York, NY: Cognizant Communication Corp.

Getz, D. (2002). Why Festivals Fail. Event Management, 7, pp. 209-219.

Getz, D. and Frisby, W. (1988). Evaluating Management Effectiveness In Community-Run Festivals. Journal of Travel Research, 27, pp. 22-27.

Getz, D., Andersson, T.D. and Larson, M. (2006). Festival Stakeholder Roles: Concepts and Case Studies. Event Management, 10, pp. 103-122.

Getz, D., Andersson, T.D. and Carlsen, J. (2010). Festival management studies. International Journal of Event and Festival Management, 1, pp. 29-59.

Granovetter, M. (1985). Economic Action and Social Structure: The Problem of Embeddedness. American Journal of Sociology, 91, pp. 481-510. 
Grappi, S. and Montanari, F. (2011). The role of social identification and hedonism in affecting tourist re-patronizing behaviours: The case of an Italian festival. Tourism Management, 32, pp. 1128-1140.

Grunwell, S. and Ha, I.S. (2007). Film Festivals: An Empirical Study of Factors for Success. Event Management, 11, pp. 201-210.

Gursoy, D., Kim, K. and Uysal, M. (2004). Perceived impacts of festivals and special events by organizers: an extension and validation. Tourism Management, 25, pp. 171-181.

Heenan, D.A. (1978). Tourism and the Community a Drama in Three Acts. Journal of Travel Research, 16, pp. 30-32.

Hudson, S., Roth, M.S., Madden, T.J. and Hudson, R. (2015). The effects of social media on emotions, brand relationship quality, and word of mouth: An empirical study of music festival attendees. Tourism Management, 47, pp. 68-76.

Hvenegaard, G.T. (2011). Potential Conservation Benefits of Wildlife Festivals. Event Management, 15, pp. 373-386.

Iqbal, M.Z., Akbar, S. and Budhwar, P. (2015). Effectiveness of Performance Appraisal: An Integrated Framework. International Journal of Management Reviews, 17, pp. 510 533.

Iso-Ahola, S.E. (1980). The Social Psychology of Leisure and Recreation. Dubuque, IA: William C Brown.

Jack, S. L. (2010). Approaches to studying networks: Implications and outcomes. Journal of Business Venturing, 25, pp. 120-137.

Jackson, J., Houghton, M., Russell, R. and Triandos, P. (2005). Innovations in Measuring Economic Impacts of Regional Festivals: A Do-It-Yourself Kit. Journal of Travel Research, 43, pp. 360-367.

Jaeger, K. and Mykletun, J.R. (2013). Festivals, Identities, and Belonging. Event 
Management, 17, pp. 213-226.

Jeong, S. and Santos, C.A. (2004). Cultural politics and contested place identity. Annals of Tourism Research, 31, pp. 640-656.

Jepson, A., Clarke, A. and Ragsdell, G. (2013). Applying the motivation-opportunity-ability (MOA) model to reveal factors that influence inclusive engagement within local community festivals. International Journal of Event and Festival Management, 4, pp. 186-205.

Jiang, J.-J., Lee, C.-L., Fang, M.-D., Tu, B.-W. and Liang, Y.-J. (2015). Impacts of Emerging Contaminants on Surrounding Aquatic Environment from a Youth Festival. Environmental Science \& Technology, 49, pp. 792-799.

Johansson, M. and Kociatkiewicz, J. (2011). City festivals: creativity and control in staged urban experiences. European Urban and Regional Studies, 18, pp. 392-405.

Julien, P.A. (2007). A Theory of Local Entrepreneurship in the Knowledge Economy. Cheltenham: Edward Elgar.

Karlsen, S. and Stenbacka Nordström, C. (2009). Festivals in the Barents Region: Exploring Festival-stakeholder Cooperation. Scandinavian Journal of Hospitality and Tourism, 9, pp. 130-145.

Kim, C., Scott, D., Thigpen, J.F. and Kim, S.-S. (1998). Economic Impact of a Birding Festival. Festival Management and Event Tourism, 5, pp. 51-58.

Kim, H. and Jamal, T. (2007). Touristic quest for existential authenticity. Annals of Tourism Research, 34, pp. 181-201.

Kim, K., Sun, J., Jogaratnam, G. and Oh, I.-K. (2006). Market Segmentation by Activity Preferences: Validation of Cultural Festival Participants. Event Management, 10, pp. 221-229. 
Kim, S.S., Prideaux, B. and Chon, K. (2010). A comparison of results of three statistical methods to understand the determinants of festival participants' expenditures. International Journal of Hospitality Management, 29, pp. 297-307.

Kruger, M. and Saayman, M. (2013). Assessing the Viability of First-Time and Repeat Visitors to an International Jazz Festival in South Africa. Event Management, 17, pp. 179-194.

Larson, M. (2002). A political approach to relationship marketing: Case study of the Storsjöyran Festival. International Journal of Tourism Research, 4, pp. 119-143.

Larson, M. (2009). Festival Innovation: Complex and Dynamic Network Interaction. Scandinavian Journal of Hospitality and Tourism, 9, pp. 288-307.

Lawton, L.J. and Weaver, D.B. (2010). Normative and innovative sustainable resource management at birding festivals. Tourism Management, 31, pp. 527-536.

Lee, C.-K., Lee, Y.-K. and Wicks, B.E. (2004). Segmentation of festival motivation by nationality and satisfaction. Tourism Management, 25, pp. 61-70.

Lee, J. and Beeler, C. (2009). An Investigation of Predictors of Satisfaction and Future Intention: Links to Motivation, Involvement, and Service Quality in a Local Festival. Event Management, 13, pp. 17-29.

Lee, J. and Kyle, G.T. (2014). Segmenting Festival Visitors Using Psychological Commitment. Journal of Travel Research, 53, pp. 656-669.

Lee, J., Kyle, G.T. and Scott, D. (2012). The Mediating Effect of Place Attachment on the Relationship between Festival Satisfaction and Loyalty to the Festival Hosting Destination. Journal of Travel Research, 51, pp. 754-767.

Lee, S.Y., Petrick, J.F. and Crompton, J. (2007). The Roles of Quality and Intermediary Constructs in Determining Festival Attendees' Behavioral Intention. Journal of Travel Research, 45, pp. 402-412. 
Lee, Y.K., Lee, C.K., Lee, S.K. and Babin, B.J. (2008). Festivalscapes and patrons' emotions, satisfaction, and loyalty. Journal of Business Research, 61, pp. 56-64.

Lin, K.-W., Stein, P. and Goldblatt, J. (2011). New Investment: An Exploratory Case Study of Three Mature Edinburgh Festivals and Their Future Funding Opportunities. Event Management, 15, pp. 179-195.

Litvin, S.W. and Fetter, E. (2006). Can a festival be too successful? A review of Spoleto, USA. International Journal of Contemporary Hospitality Management, 18, pp. 41-49. Litvin, S.W., Crotts, J.C., Blackwell, C. and Styles, A.K. (2006). Expenditures of Accommodations Tax Revenue: A South Carolina Study. Journal of Travel Research, 45, pp. 150-157.

Litvin, S.W., Pan, B. and Smith, W. (2013). Festivals, special events, and the "rising tide". International Journal of Culture, Tourism and Hospitality Research, 7, pp. 163-168.

Mabey, C. (2013). Leadership Development in Organizations: Multiple Discourses and Diverse Practice. International Journal of Management Reviews, 15, pp. 359-380.

Macpherson, A. and Jones, O. (2010). Editorial: Strategies for the Development of International Journal of Management Reviews. International Journal of Management Reviews, 12, pp. 107-113.

McKercher, B., Mei, W.S. and Tse, T.S.M. (2006). Are Short Duration Cultural Festivals Tourist Attractions? Journal of Sustainable Tourism, 14, pp. 55-66.

Mason, M.C. and Paggiaro, A. (2012). Investigating the role of festivalscape in culinary tourism: The case of food and wine events. Tourism Management, 33, pp. 1329-1336.

Maslow, A.H. (1943). A Theory of Human Motivation. Psychological Review, 50, pp. 370-396. Matheson, C.M., Rimmer, R. and Tinsley, R. (2014). Spiritual attitudes and visitor motivations at the Beltane Fire Festival, Edinburgh. Tourism Management, 44, pp. 16-33.

Nolan, C.T. and Garavan, T.N. (2015). Human Resource Development in SMEs: A 
Systematic Review of the Literature. International Journal of Management Reviews. DOI: 10.1111/ijmr.12062 (early online publication).

Nurse, K. (2004). Trinidad Carnival: Festival Tourism and Cultural Industry. Event Management, 8, pp. 223-230.

Oh, M.-J. and Lee, T.J. (2012). How Local Festivals Affect the Destination Choice of Tourists. Event Management, 16, pp. 1-9.

Oliver, R.L. (1997). Satisfaction: A behavioral perspective on the consumer. New York, NY: McGraw-Hill.

Organ, K., Koenig-Lewis, N., Palmer, A. and Probert, J. (2015). Festivals as agents for behaviour change: A study of food festival engagement and subsequent food choices. Tourism Management, 48, pp. 84-99.

O'Sullivan, D. and Jackson, M.J. (2002). Festival Tourism: A Contributor to Sustainable Local Economic Development? Journal of Sustainable Tourism, 10, pp. 325-342. Prentice, R. and Andersen, V. (2003). Festival as creative destination. Annals of Tourism Research, 30, pp. 7-30.

Pret, T., Shaw, E. and Drakopulou Dodd, S. (2015). Painting the full picture: The conversion of economic, cultural, social and symbolic capital. International Small Business Journal. DOI: 10.1177/0266242615595450 (early online publication)

Tomljenovic, R. and Weber, S. (2004). Funding cultural events in Croatia: Tourism-related policy issues. Event Management, 9, pp. 51-59.

Quinn, B. (2005). Arts Festivals and the City. Urban Studies, 42, pp. 927-943.

Quinn, B. (2006). Problematising ‘Festival Tourism': Arts Festivals and Sustainable Development in Ireland. Journal of Sustainable Tourism, 14, pp. 288-306.

Rao, V. (2001). Celebrations as Social Investments: Festival Expenditures, Unit Price Variation and Social Status in Rural India. The Journal of Development Studies, 38, 
pp. 71-97.

Robertson, M. and Rogers, P. (2009). Festivals, Cooperative Stakeholders and the Role of the Media: A Case Analysis of Newspaper Media. Scandinavian Journal of Hospitality and Tourism, 9, pp. 206-224.

Rogers, P. and Anastasiadou, C. (2011). Community Involvement in Festivals: Exploring Ways of Increasing Local Participation. Event Management, 15, pp. 387-399.

Rollins, R. and Delamere, T. (2007). Measuring the social impact of festivals. Annals of Tourism Research, 34, pp. 805-808.

Rowlinson, M., Harvey, C., Kelly, A. and Morris, H. (2011). The use and abuse of journal quality lists. Organization, 18, pp. 443-446.

Saleh, F. and Ryan, C. (1993). Jazz and knitwear: Factors that attract tourists to festivals. Tourism Management, 14, pp. 289-297.

Seaton, A.V. (1997). Unobtrusive Observational Measures as a Qualitative Extension of Visitor Surveys at Festivals and Events: Mass Observation Revisited. Journal of Travel Research, 35, pp. 25-30.

Shin, H. (2004). Cultural festivals and regional identities in South Korea. Environment and Planning D: Society and Space, 22, pp. 619-632.

Slotte-Kock, S. and Coviello, N. (2010). Entrepreneurship research on network processes: a review and ways forward. Entrepreneurship Theory and Practice, 34, pp. 31-57.

Small, K. (2007). Social Dimensions of Community Festivals: An Application of Factor Analysis in the Development of the Social Impact Perception (SIP) Scale. Event Management, 11, pp. 45-55.

Smith, W.W., Litvin, S.W. and Canberg, A. (2010). Setting parameters: operational budget size and allocation of resources. International Journal of Event and Festival Management, 1, pp. 238-243. 
Song, H.J., Lee, C.-K., Kang, S.K. and Boo, S.-j. (2012). The effect of environmentally friendly perceptions on festival visitors' decision-making process using an extended model of goal-directed behavior. Tourism Management, 33, pp. 1417-1428.

Song, Z., Xing, L. and Chathoth, P.K. (2014). The effects of festival impacts on support intentions based on residents' ratings of festival performance and satisfaction: a new integrative approach. Journal of Sustainable Tourism, 23, pp. 316-337.

Stadler, R., Reid, S. and Fullagar, S. (2013). An ethnographic exploration of knowledge practices within the Queensland Music Festival. International Journal of Event and Festival Management, 4, pp. 90-106.

Strauss, A. and Corbin, J. (1990). The Basics of Qualitative Research. London: Sage.

Thompson, K. and Schofield, P. (2009). Segmenting and Profiling Visitors to the Ulaanbaatar Naadam Festival by Motivation. Event Management, 13, pp. 1-15.

Thrane, C. (2002). Jazz Festival Visitors and Their Expenditures: Linking Spending Patterns to Musical Interest. Journal of Travel Research, 40, pp. 281-286.

Tkaczynski, A. (2013). A Stakeholder Approach to Attendee Segmentation: A Case Study of an Australian Christian Music Festival. Event Management, 17, pp. 283-298.

Tkaczynski, A. and Stokes, R. (2010). Festperf: A Service Quality Measurement Scale for Festivals. Event Management, 14, pp. 69-82.

Tkaczynski, A. and Rundle-Thiele, S.R. (2011). Event Segmentation: A Review and Research Agenda. Tourism Management, 32, pp. 426-434.

Tranfield, D., Denyer, D. and Smart, P. (2003). Towards a methodology for developing evidence-informed management knowledge by means of systematic review. British Journal of Management, 14, pp. 207-222.

Uysal, M., Gahan, L. and Martin, B. (1993). An examination of event motivations: A case study. Festival Management and Event Tourism, 1, pp. 5-10. 
Uysal, M. and Gitleson, R. (1994). Assessment of economic impacts: Festivals and special events. Festival Management and Event Tourism, 2, pp. 3-9.

Van Aalst, I. and van Melik, R. (2012). City festivals and urban development: does place matter? European Urban and Regional Studies, 19, pp. 195-206.

Van Den Berg, M. (2012). Femininity As a City Marketing Strategy: Gender Bending Rotterdam. Urban Studies, 49, pp. 153-168.

Van Winkle, C.M. and Woosnam, K.M. (2014). Sense of community and perceptions of festival social impacts. International Journal of Event and Festival Management, 5, pp. 22-38.

Van Zyl, C. and Botha, C. (2004). Motivational factors of local residents to attend the Aardklop National Arts Festival. Event Management, 8, pp. 213-222.

Vestrum, I. (2014). The embedding process of community ventures: creating a music festival in a rural community. Entrepreneurship and Regional Development, 26, pp. 619-644.

Wamwara-Mbugua, L.W. and Cornwell, T.B. (2009). Visitor Motivation to Attending International Festivals. Event Management, 13, pp. 277-286.

Wang, C.L. and Chugh, H. (2014). Entrepreneurial Learning: Past Research and Future Challenges. International Journal of Management Reviews, 16, pp. 24-61.

Wang, N. (2000). Tourism and Modernity: A Sociological Analysis. Oxford: Pergamon. Waterman, S. (1998). Carnivals for elites? The cultural politics of arts festivals. Progress in Human Geography, 22, pp. 54-74.

Whitford, M. (2008). Oaxaca's Indigenous Guelaguetza Festival: Not all that Glistens is Gold. Event Management, 12, pp. 143-161.

Whitford, M. and Dunn, A. (2014). Papua New Guinea's Indigenous Cultural Festivals: Cultural Tragedy or Triumph? Event Management, 18, pp. 265-283. 
Whitford, M. and Ruhanen, L. (2013). Indigenous Festivals and Community Development: A Sociocultural Analysis of an Australian Indigenous Festival. Event Management, 17, pp. 49-61.

Willems-Braun, B. (1994). Situating cultural politics: fringe festivals and the production of spaces of intersubjectivity. Environment and Planning D: Society and Space, 12, pp. 75-104.

Willmott, H. (2011). Listing perilously. Organization, 18, pp. 447-448.

Wood, G. and Peel, D. (eds) (2015). Association of Business Schools Academic Journal Guide 2015. London: Association of Business Schools.

Woosnam, M.K., Van Winkle, M.C. and An, S. (2013). Confirming the Festival Social Impact Attitude Scale in the Context of a Rural Texas Cultural Festival. Event Management, 17, pp. $257-270$.

Woosnam, M.K., Van Winkle, M.C. and An, S. (2013). Confirming the Festival Social Impact Attitude Scale in the Context of a Rural Texas Cultural Festival. Event Management 17, pp. 257-270.

Yolal, M., Woo, E., Cetinel, F. and Uysal, M. (2012). Comparative research of motivations across different festival products. International Journal of Event and Festival Management, 3, pp. 66-80.

Yoon, Y.-S., Lee, J.-S. and Lee, C.-K. (2010). Measuring festival quality and value affecting visitors' satisfaction and loyalty using a structural approach. International Journal of Hospitality Management, 29, pp. 335-342.

Yuan, J. and Jang, S. (2008). The Effects of Quality and Satisfaction on Awareness and Behavioral Intentions: Exploring the Role of a Wine Festival. Journal of Travel Research, 46, pp. 279-288. 


\section{Supporting Information}

Additional Supporting Information may be found in the online version of this article at the publisher's website:

Appendix S1: Steps in the systematic literature review

Appendix S2: Sample Selection Process

Appendix S3: Most frequently cited articles in this review

Appendix S4: Festival research themes

Appendix S5: Summary of the 160 reviewed articles

Appendix S6: Subject categories and selected journals (featuring relevant festival studies)

Appendix S7: Full reference list of the reviewed articles 